\title{
MODIFICATION OF VESTIBULAR SENSITIVITY IN THE RAT
}

David C. Riccio, Makoto lgaroshi, and Amold Eskin

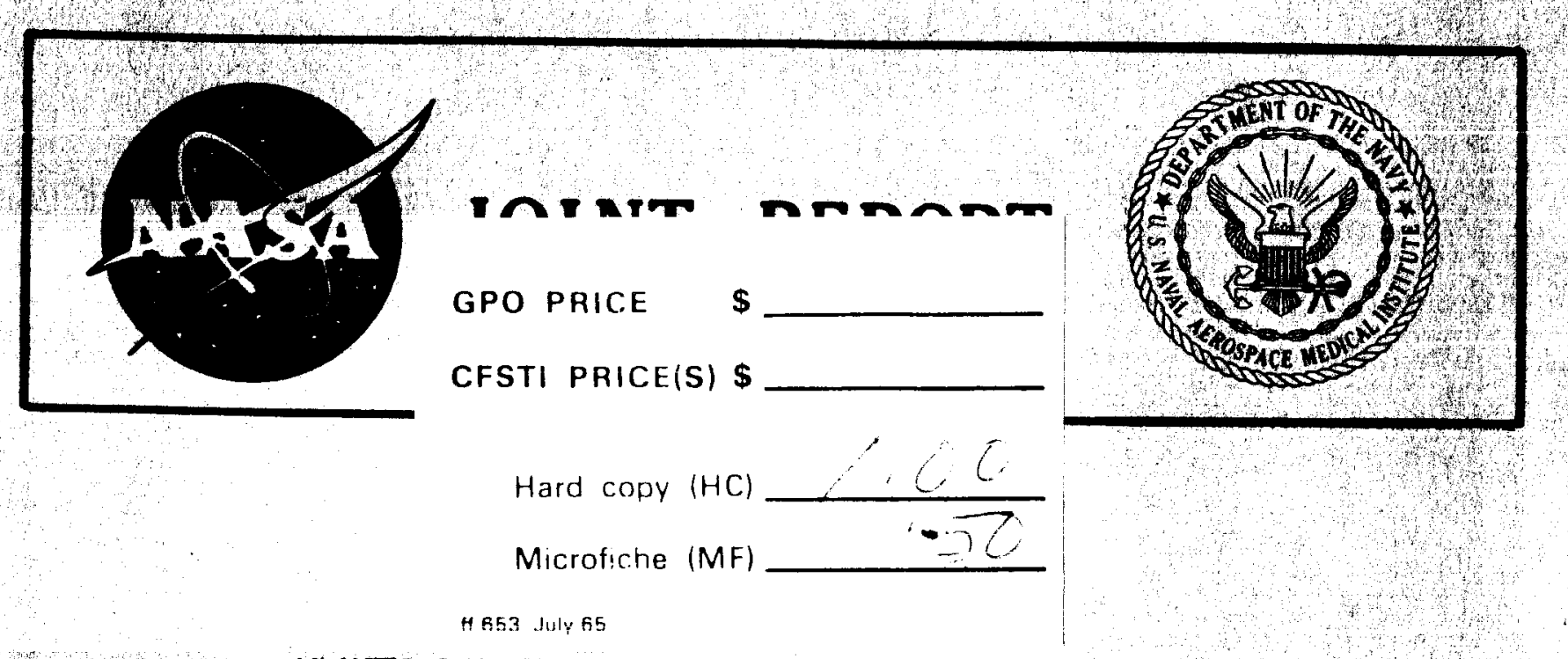

UNITED STA TES NAVAL AEROSPACE MEDICAL INSTITUTE

NATIONAL AERONAUTICS AND SPACE ADMINISTRATION

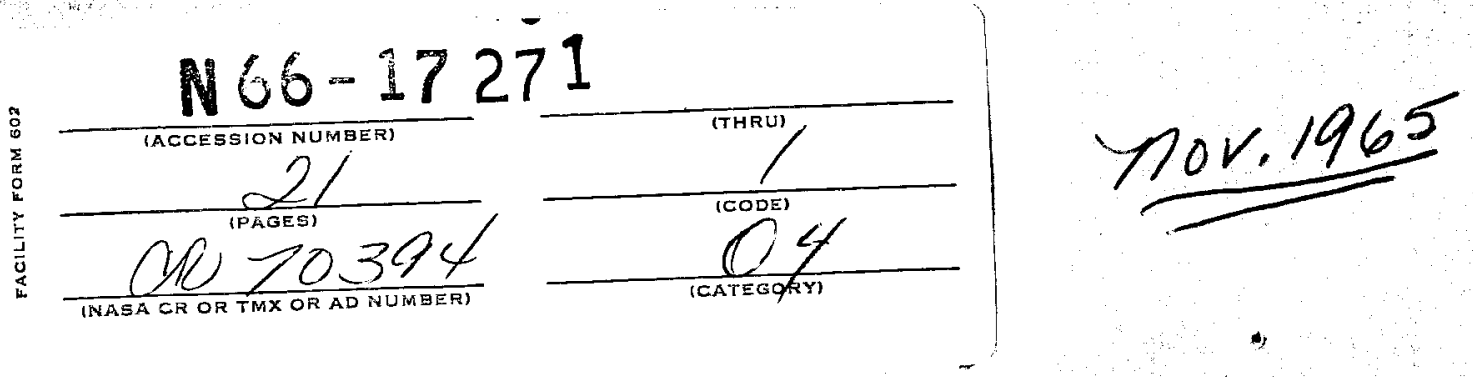

Distribution of this document is unlimited. 
Distribution of this document is unlimited.

\title{
MODIFICATION OF VESTIBULAR SENSITIVITY IN THE RAT* \\ David C. Riccio, Makoto Igarashi, and Arnold Eskin
}

\author{
Bureau of Medicine and Surgery \\ Project MR005.13-6001 \\ Subtask $1 \quad$ Report No.125 \\ NASA Order No.R-93
}

\author{
Approved by \\ Captain Ashton Graybiel, MC USN \\ Director of Research
Released by
Captain H. C. Hunley, MC USN
Commanding Officer

17 November 1965

*This research was conducted under the sponsorship of the Office of Advanced Research and Technology, National Aeronautics and Space Administration.

\author{
U. S. NAVAL AEROSPACE MEDICAL INSTITUTE \\ U. S. NAVAL AVIATION MEDICAL CENTER \\ PENSACOLA, FLORIDA
}




\section{THE PROBLEM}

To determine the effects of vestibular damage or previous vestibular stimulation on the spontaneous activity of the rat during rotation.

\section{FINDINGS}

Unilateral destruction of the labyrinth through intratympanic injections of streptomycin sulfate decreased the sensitivity of unrestrained rats to rotation, as measured by the maintenance of high levels of spontaneous locomotor activity during rotation. Repeated exposure to rotation produced a similar threshold shift in undamaged rats. Normal control animals showed a marked decrement in activity while rotated. Rats were extremely resistant to streptomycin sulfate injected systemically; neither morphological damage to hair cells nor changes in the response to vestibular stimulation was found following a total dosage of $10,000 \mathrm{mg}$ of the drug. The findings demonstrated that the spontaneous activity levels provide a sensitive behavioral measure of the effects of vestibular stimulation on the rat.

\section{ACKNOWLEDGMENTS}

The authors wish to thank $\mathrm{Dr}$. Dietrich Beischer for his continued support and encouragement. The technical assistance of Mr. Samuel M. Lansdon, Miss Constance N. Coulter, and Mrs. Beth Boss is gratefully acknowledged. 


\section{INTRODUCTION}

Surprisingly little data are available concerning the function of the vestibular system in the rat. Unlike the cat or the dog, the rat has not been the subject of choice for experimental investigations of labyrin thine functioning, in spite of $i$ ts otherwise extensive use in modern biological and psychological research. The advantages of extending vestibular research to the rat seem clear. In addition to being easily maintained, rats are inexpensive enough to be discarded after a single use, thus avoiding problems inherent in repeated testing. Genetic inbreeding insures a reasonably homogenous population of subjects. Equally important, nearly complete environmental control can be exerted over their entire life span so that past histories with respect to prior vestibular stimulation, disease, and numerous other factors influencing vestibular functioning can be known and controlled.

Since the rat does not vomit (6) or display other readily observable physiological symptoms of vestibular stimulation, it has apparently been considered either insensitive to motion-produced stimuli or refractory to practical measurement of their effects. A recent study (3), however, demonstrated that the rat is in fact quite sensitive to rotation, as measured behaviorally by changes in spontaneous locomotor activity. Activity levels were found to decrease in a systematic fashion with increasing angular velocities and duration of exposure. Since centrifugal forces were inconsequential at speeds producing a major decline in activity, the disruption of ongoing behavior was attributed to the unusual vestibular stimulation from Coriolis forces (5) generated by the subjects' movements.

In view of possible further use of the rat in rotation experiments, it was felt that more direct evidence for the role of the vestibular system in mediating the behavioral response to rotation was needed. Another aim was to determine whether the activity measure could be used as an assay for modifications of vestibular sensitivity. It is well known that damage to the vestibular end organ reduces nystagmus and vomiting responses to motion-produced stimuli in a number of species $(9,10,15)$. It is also well established that repeated exposure to accelerative stimuli can appreciably al ter the sensitivity of an organism, although no damage to the labyrinth is involved. If the activity decrease of the rat during rotation were due to vestibular functioning, then these same experimental manipulations should also reduce the behavioral response to subsequent stimulations. Accordingly, the major purpose of this study was to determine whether the rats' activity responses during rotation would be modified by end organ damage or previous rotational experience. 
In order to assess the role of vestibular stimulation, this experiment compared the spontaneous activity of normal, habituated and labyrinthine destroyed rats when exposed to the rotatory environment. Initially an attempt was made to determine relative sensitivity in rats with (a) only one labyrinth destroyed and (b) both labyrinths destroyed. To determine the effects of an environmental variable, a group of intact animals was tested after repeated exposure to rotation. Thus, the over-all plan was to compare the sensitivity to rotation among four groups: 1) normal controls, 2) habituated, 3) unilaterally ablated, and 4) bilaterally ablated (attempted).

\section{SUBJECTS AND APPARATUS}

Twenty-one adult male albino Sprague-Dawley rats were used as the experimental subjects.

The activity chamber in which the rat was contained was an enclosed arena 2 feet square with 6-inch sides of clear Plexiglas to permit observation of the animal. A removable cover with air holes reduced the illumination in the field and prevented the rat's escape. The activity box was mounted on a rotation turntable which allowed a seated observer convenient observation of the rat through the sides of the chamber.

\section{METHOD}

\section{Vestibular Destruction}

To produce destruction of the unilateral labyrinth, streptomycin sulfate was administered directly into one middle ear cavity of 11 rats. Each rat was restrained under light anesthesia with the intraperitoneal injection of $0.25 \mathrm{ml}$ of Nembutal, and about $250 \mathrm{mg}$ of streptomycin sulfate solution were injected into the tympanic cavity. The animal was left in restraint for several hours to prevent the drug being shaken out. Treatment was repeated until clinical signs of destruction, such as head tilting and spinning when lifted by the tail, were evident. Six of the eleven rats showed these signs before the tenth injection. Three rats which showed no observable changes after twenty in jections were discarded. Two others died before showing signs of damage.

A second group of three rats received systemic injections (intramuscular) of streptomycin sulfate $100 \mathrm{mg}$ daily. Over $150 \mathrm{mg}$ injected daily were previously found to be fatal. Since no behavioral signs of gradual bi lateral labyrinthine involvement were apparent, injections were continued until the subject received a total dosage of more than $10,000 \mathrm{mg}$ of streptomycin. Although the rat is reported to be relatively resistant to streptomycin (8), it was expected that this very high dose would produce damage to both labyrinths. 
Animals with unilateral destruction were tested between the second and fourth week following their final injection. The systemically injected rats were tested after ten weeks of injections in which time they had received a cumulative dosage of $5,000 \mathrm{mg}$ and again after twenty weeks, when the total dosage of over 10,000 $\mathrm{mg}$ of streptomycin sulfate had been given.

\section{Histology}

After completion of rotation tests, representative animals were sacrificed. Slides for light microscopic investigation were prepared following the routine procedures of temporal bone preparation; i.e., fixed in Heidenhain-Susa fixative, decalcified with $5 \%$ trichloroacetic acid, dehydrated by ethanol, neutralized, embedded in celloidin, serially sectioned in horizontal plane at 20 microns, and stained in Hematoxylin-Eosin.

Habituation

Since exploratory activity in a closed arena tends to diminish after several tests as the animals become familiar with the situation, habituation to rotation was produced independently of the activity measure as follows: Three rats trained to bar press for food reward were exposed to rotation speeds which increased in one RPM increments every five minutes. As measured by the lowest speed required to totally suppress responding, initial rotation tolerance was between 9 and 11 RPM. Habituation developed as a function of repeated exposures. After ten to fifteen daily tests, animals responded up to 17 to $20 \mathrm{RPM}$, a median increase in tolerance of about 80 per cent. A more detailed description of the development of habituation is in preparation (13).

\section{Controls}

To insure that no systematic variations were occurring, an additional group of four naive rats was run. Conditions were the same as those employed to establish the effects of various angular velocities on activity. Tests of the controls were interspersed with those of the experimental groups. Since all animals were placed in the chamber by a second experimenter, the observer was not aware of the group to which they belonged.

Rotation Tests

To test rotational sensitivity, the animals were exposed to a speed of 12 RPM for six minutes. Previous study had established that activity levels decrease by about 70 per cent in normal animals under these conditions. It may be noted that the increase in $G$ level at the furthest point from the center of turntable would be only 0.005 .

The procedure consisted of placing each animal in the closed arena on the turntable and recording its activity during a six-minute baseline period (no rotation) and a sixminute rotation period. There was a thirty-second nonscoring period after rotation started to allow angular acceleration effects to subside. Details of activity scoring are 
described more fully elsewhere (3). In brief, the animal was observed during al ternate ten-second periods and rated on activity on a scale of 3 points for continuous running to 0 points for no observable movement. Three periods were totalled together to give the score for that minute. Tests were run in the evening under dim illumination.

\section{RESULTS}

\section{FUNCTIONAL TEST}

Figure 1 presents the median activity rate each minute for the four groups prior to and during rotation. Since responses of the four control animals were within the previously established range of normal animals, their data were pooled with an original group of seven rats from a previous study to give a total control population of eleven animals. Histological findings (to be described below) indicated that the three systemically injected rats did not suffer labyrin thine destruction and thus were essentially normal functioning animals. As would be expected then, data from rotation tests of both systemic and control groups were similar. The curve shown (Figure 1) for systemically in jected rats is based on scores obtained from the three rats on their initial rotation exposure. The curves for unilateral and habituated animals represent sample sizes of six and three rats, respectively.

It can be seen that the prerotation or baseline measures were comparable for all groups. During rotation, however, both the controls and systemically injected groups showed a similar pattern of marked activity decline. In contrast, the unilateral and habituated groups showed much smaller decrease in activity. While the small number of subjects in the groups precludes a definite statement on the exact shape of the curves, it is evident that the habituated and unilateral groups plateau at a higher level of activity. After several minutes of rotation the controls and systemically injected animals became almost completely motionless, holding a statue-like "freeze" posture. Only occasional slight head movements occurred. On the other hand, the adapted and unilaterally destroyed rats showed reduced activity but continued to walk around or engage in sniffing and grooming behavior. When the activity rates are compared for the last three minutes of treatment, during which the effects of rotation have more completely taken effect, the difference between the control group and the unilaterally damaged group is significant at $p=.002$ (Mann-Whitney $U$ test, two tailed). The activity of the habituated group is also significantly higher than the controls $(p<.02)$ (Mann-Whitney $U$ test, two tailed). No significant difference was found between the control and systemically injected (but intact) groups, or between the adapted and uni laterally damaged animals. 


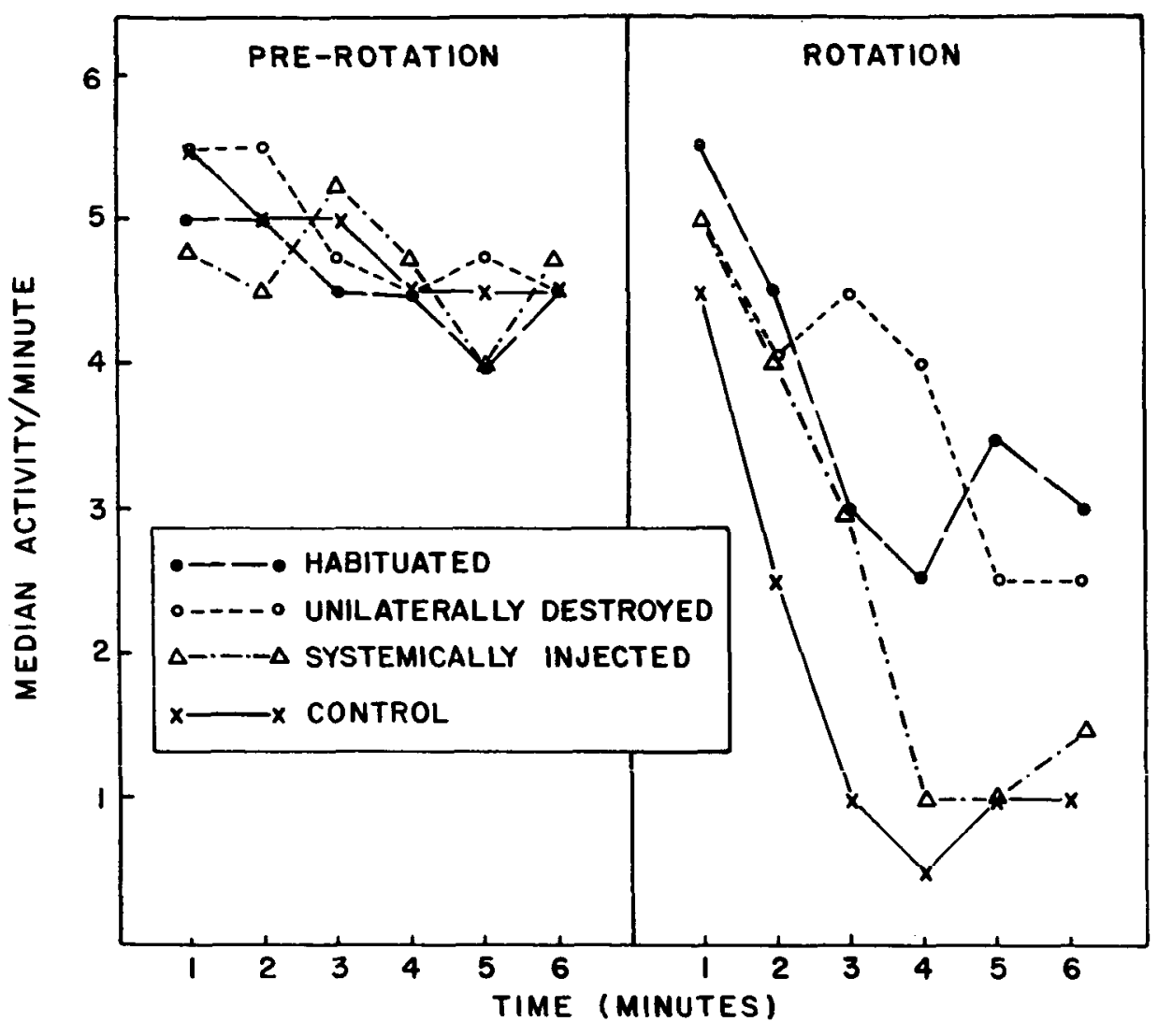

Figure 1

Median Activity Levels During Baseline and Rotation Periods

\section{HISTOLOGICAL FINDINGS}

Intratympanic Injection Group

Figures $2 A, B$ and $3 L, R$ demonstrate the representative findings. Significant hair cell loss in the organ of Corti, as well as in the cristae of the semicircular canals and maculae, was observed in four of the six unilaterally injected rats. The supporting structures were generally intact except for the complete destruction of the organ of Corti at the basal turn of the cochlea. In general, the spiral ganglion was involved fairly severely while the vestibular ganglion was not. In the remaining two rats, the hair cell lesion was rather slight and insignificant.

Parenteral Injection Group

Although well over $10,000 \mathrm{mg}$ of streptomycin sulfate were systemically injected, all three animals were without any detectable hair cell lesion. All of the canal cristae, maculae, and organ of Corti were morphologically intact. 


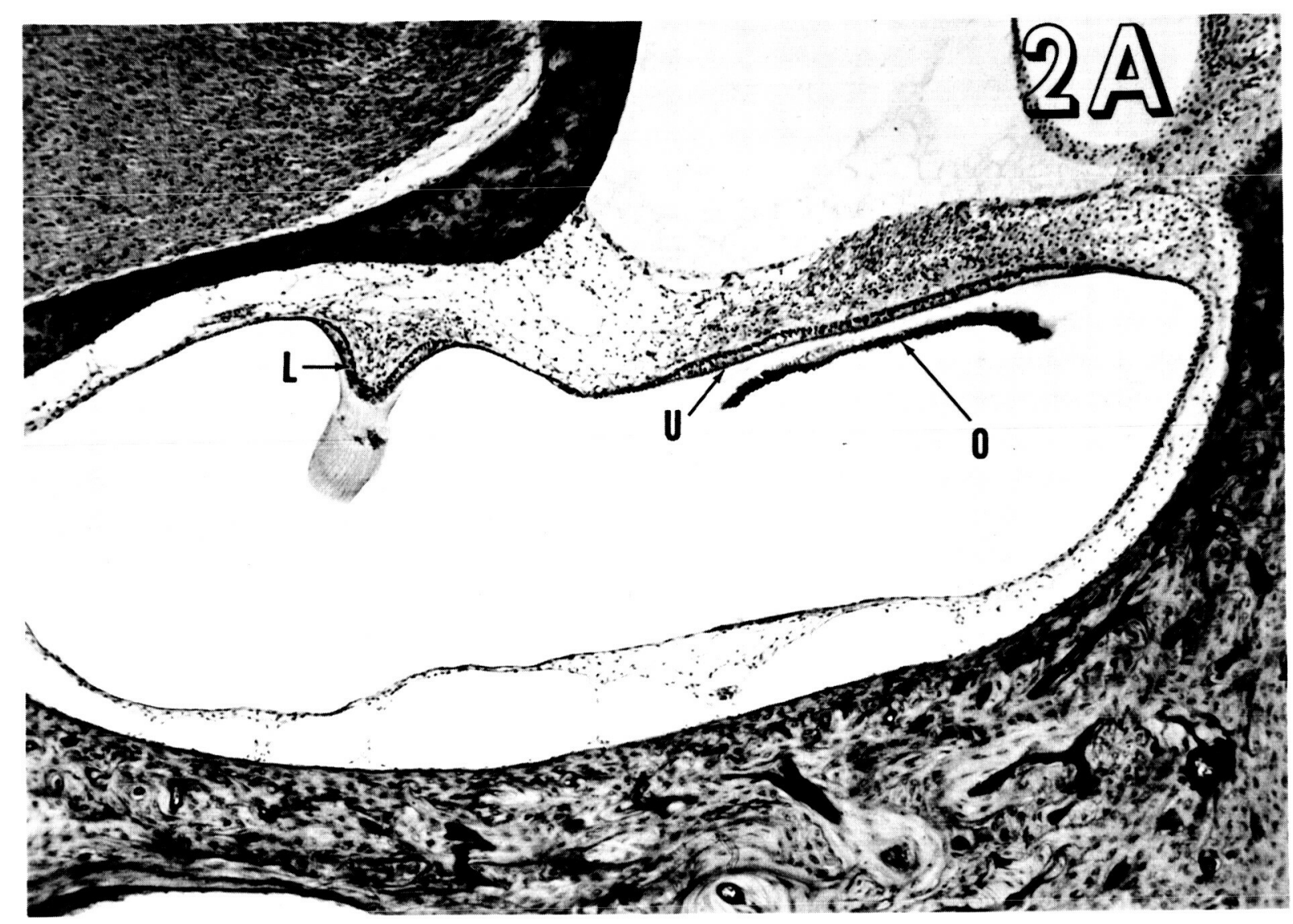

Figure 2A

Microphotograph shows the crista of the lateral semicircular canal (L) and the utricular macula (U) from the rat which was administered $250 \mathrm{mg}$ of streptomycin sulfate intratympanically. Otolithic membrane $(\mathrm{O})$ is intact. $105 \times$ 


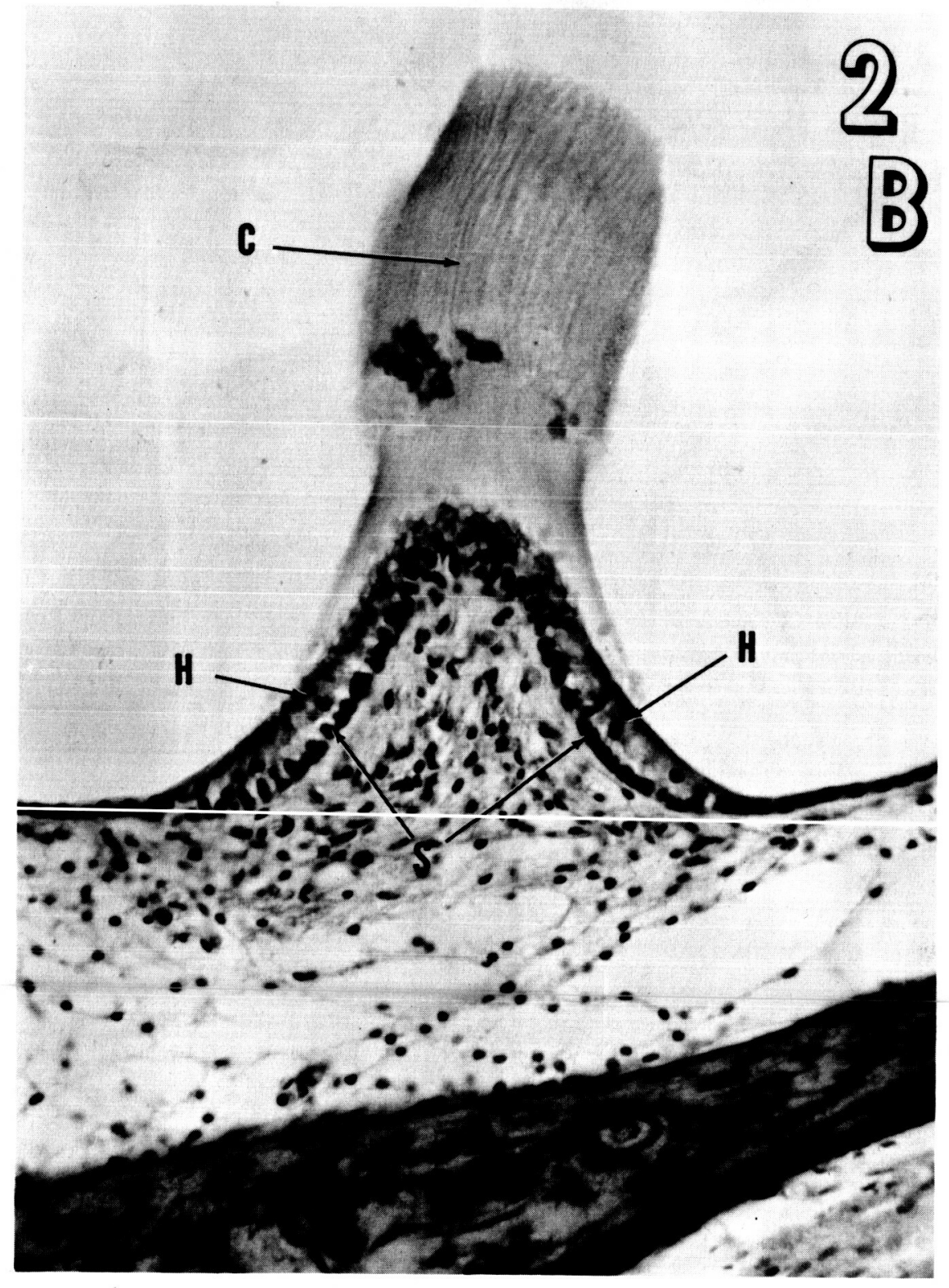

Figure 2B

High magnification view of the lateral canal crista from the same rat ear. Note the hair cell loss. S: Supporting cells. H: Hair cells (remaining). C : Cupula. $450 x$ 

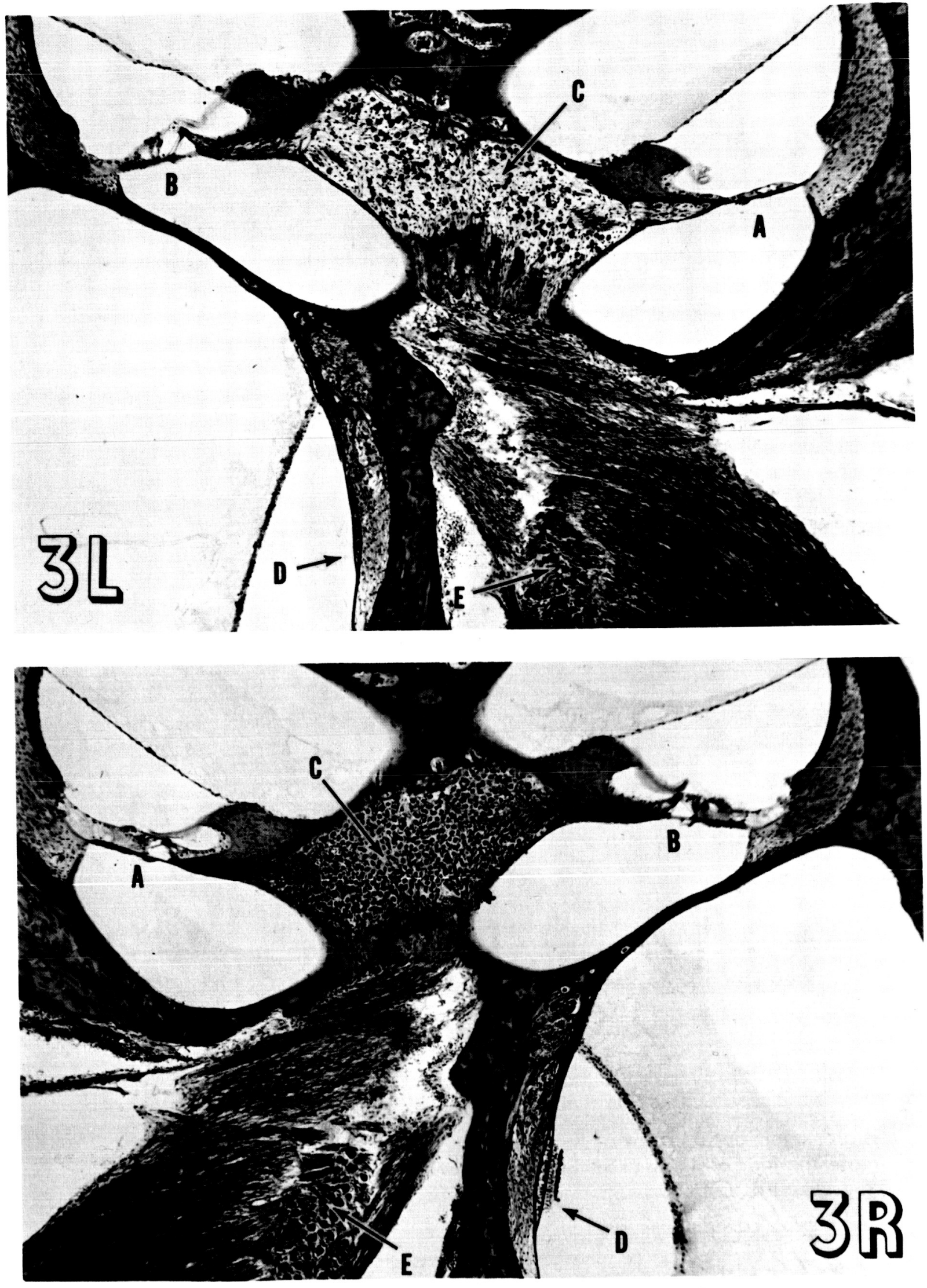
Figures $3 \mathrm{~L}$ and $3 \mathrm{R}$

Views from Streptomycin Injected Ear $(L)$ and Noninjected Ear $(R)$ from the Same Rat.
A: Organ of Corti in the lower basal turn
B: Organ of Corti in the upper basal turn
C: Spiral ganglion in the basal turn
D: Saccular macula
E: Scarpa's ganglion (vestibular ganglion)

Notice, in the injected ear (L), destruction of organ of Corti (A), loss of outer hair cells (B), loss of spiral ganglion cells (C), and loss of otolithic membrane and hair cells in macula sacculi (D). $90 \times$ 
Thus, the data indicate that destruction of the hair cells of the canal cristae in one labyrinth considerably reduces a rat's sensitivity to rotation. Decreased sensitivity in this experiment is reflected in greater spontaneous activity of the subjects; that is, the rat responded more nearly as if it were in a stable, nonrotating environment. Activity levels remained significantly higher than those of normal controls during the rotational exposure. Although the systemic injection of rats failed to produce bilateral labyrinthine destruction as had initially been intended, the marked shift in threshold when the unilateral labyrinth is destroyed leaves little doubt as to the importance of the vestibular system in mediating the activity decline during rotation. The disruption of ongoing behavior in undamaged rats upon exposure to rotation seems clearly attributable to the unusual vestibular stimulation and conflicting proprioceptive input.

A shift in motion sickness thresholds during exposure of squirrel monkeys to slow rotation following unilateral labyrinthectomy also has been reported by Johnson, ef al., (10). Those authors also noted that the monkeys regained their sensitivity after a long postoperative period. Thus, by six months after unilateral labyrinthectomy, the motion sickness thresholds had returned to their original level. It is not yet known whether the rotation thresholds of rats also return to normal levels over a comparable period. Further investigation is now in process.

In an early study of vestibular functioning in rats, Griffith (4) found diminished postrotation nystagmus (i.e., habituation) following repeated exposures at 40 RPM. Even with the much slower speeds employed in the present study, it is clear that the behavorial response also changes with increased rotational experience. Although the initial habituating exposures to rotation took place while the rat was engaged in a bar pressing task, the rotation test for increased tolerance involved exploratory and locomotor responses under quite different experimental conditions. The considerable amount of positive transfer of habituation is probably attributable to basic similarities in motionproduced stimuli impinging on the rat in both situations. Since the rats showed some decline in activity at 12 RPM, whereas their bar pressing rates during habituation were relatively undiminished at the same speed (13), the transfer of tolerance was not complete. However, the habituation training procedure utilized slowly increasing speeds rather than sudden exposures to a particular velocity. Differences between the training and test situations in motivational and other controlling stimuli could also account for the lack of complete transfer.

The remarkable resistance of rats to the systemical use of streptomycin (8) was confirmed functionally as well as histologically by our present investigation. The lack of hair cell lesions in the rat after the extensive and prolonged systemic use of streptomycin sulfate is in sharp contrast with data from other species. Extensive morphological and functional damage is usually produced even with the lesser comparable dosages of streptomycin sulfate in the squirrel monkey, cat, and guinea pig $(7,9,11,14)$. 
The major significance of these findings is in showing that the spontaneous activity response reflects the effects of rotation following experiential and organismic changes in a fashion similar to the more traditional physiological indices. In addition, the vestibular apparatus is definitely implicated in mediating the activity changes. The behavioral meas ure thus appears to provide a valid and sensitive test of the effects of vestibular stimulation in the rat. The relationship of the activity decrement produced by rotation in intact animals to what is termed "motion sickness" in other species is of considerable interest. While the lack of a criterion end point such as vomiting precludes direct comparison, the disruption of behavior might well be related to physiological consequence of sickness. Moreover, vestibular stimulation is reported to produce an activity decline prior to vomiting in squirrel monkeys and dogs. In any case, if wellknown antimotion sickness drugs can be shown also to modify the rat's response to rotation, this behavioral index might provide a first step for rapid initial screening or assessment of new drugs in lower animals. It may also provide a useful measure in experiments dealing with the basic functions of the vestibular system. 


\section{REFERENCES}

1. Clark, B., and Graybiel, A., Human performance during adaptation to stress in the Pensacola Slow Rotation Room. Aerospace Med., 32:93-106, 1961.

2. Dodge, R., Habituation to rotation. J. exp. Psychol., 6:1-35, 1923.

3. Eskin, A., and Riccio, D. C., Changes in spontaneous activity as a measure of sensitivity to rotation in the white rat. NSAM-913. NASA Order No. R-93. Pensacola, Florida: Naval School of Aviation Medicine, 1965.

4. Griffith, C., The effect upon the white rat of continued bodily rotation. Amer. Nat., 54:524-534, 1920.

5. Guedry, F. E., Jr., and Montague, E. K., Quantitative evaluation of the vestibular Coriolis reaction. Aerospace Med., 32:487-500, 1961.

6. Hatcher, R. A., The mechanism of vomiting. Physiol. Rev., 4:479-504, 1924.

7. Hawkins, J. E., Jr., and Lurie, M. H., The ototoxicity of streptomycin. Ann. Otol., 61:789-806, 1952 .

8. Hawkins, J.E., Jr., Wolcott, H., and O'Shanny, W. J., Ototoxic effects of streptomycin and dihydrostreptomycin pantothenates in the cat. Antibiotics Annual, 554-563, 1956-1957.

9. Igarashi, M., McLeod, M. E., and Graybiel, A., Clinical pathological correlations in squirrel monkeys after suppression of semicircular canal function by streptomycin sulfate. Acta otolaryng., Stockh. In press.

10. Johnson, W. H., Meek, J. C., and Graybiel, A., The effects of unilateral and bilateral labyrinthectomy on canal sickness in the squirrel monkey. Ann. Otol. $71: 289-298,1962$.

11. McGee, T. M., and Olszewski, J., Streptomycin and dihydrostreptomycin toxicity. Arch. Otolaryng., 75:295-311, 1962.

12. Noble, R. L., Adaptation to experimental motion sickness in dogs. Amer. J. Physiol., 154:443-450, 1948.

13. Riccio, D. C., and Thach, J. S., Jr., A behavioral study of habituation to rotational stimulation in the rat. In preparation. 
14. Ruedi, L., Furrer, W., Luthy, F., Nager, G., and Tschirren, B., Further observations concerning the toxic effects of streptomycin and quinine on the auditory organs of guinea pigs. Laryngoscope, 62:333-351, 1952.

15. Wang, S. C., and Chinn, H. I., Experimental motion sickness in dogs: Importance of labyrinth and vestibular cerebellum. Amer. J. Physiol., 187:617-623, 1956.

16. Wendt, G.R., Man and motion. In: Field, J., and Magoun, H. W., (Eds.), Handbook of Physiology. Vol. 13. Adaptation to the Environment. Washington, D. C.: American Physiological Society, 1964. Pp 999-1004. 


\section{DOCUMENT CONTROL DATA - R\&D}

(Securfty claseification of title, body of abstract and indexins ennotation muat be entered whon the ovorall report is classifiod)

U. S. Naval Aerospace Medical Institute Pensacola, Florida 2a. REPORT SECURITY CLASSIFICATION 2b. GROUP

3. REPOAT THTLE

Modification of Vestibular Sensitivity in the Rat

4. DESCAIPTIVE NOTES (Type of roport and incluelve doten)

5. AUTHOR(S) (Leat name, firet neme, inillal)

Riccio, David C; Igarashi, Makoto; Eskin, Arnold

\begin{tabular}{|c|c|c|}
\hline 6. REPORT DATE 17 November 1965 & $\begin{array}{l}\text { 7Q. TOTAL NO. OF PAGES } \\
13\end{array}$ & $\begin{array}{c}\text { 7b. NO. OF REFs } \\
16\end{array}$ \\
\hline $\begin{array}{l}\text {-9. CONTRACT OR GRANT NO. NASA R-93 } \\
\text { 6. PROJECT NO. } \\
\text { MRO05, 13-6001 Subtask } 1\end{array}$ & \multicolumn{2}{|c|}{$\begin{array}{l}\text { 9. ORIGINATOR'S AEPORT NUMBER(S) } \\
\text { NAMI - } 950\end{array}$} \\
\hline c. & \multicolumn{2}{|c|}{ 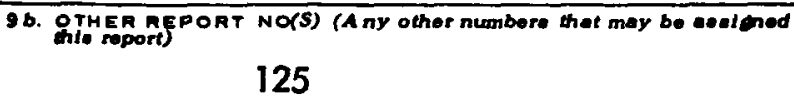 } \\
\hline
\end{tabular}

10. AVAILABILITY/LIMITATION NOTICES Qualified requesters may obtain copies of this report from DDC. Available, for sale to the public, from the Clearinghouse for Federal Scientific and Technical Information, Springfield, Virginia 22151.

Spontaneous locomotor activity was measured in 21 unrestrained rats individually exposed to rotation. In accordance with previous findings, normal control rats showed a marked decrement in activity during rotation. In contrast, animals with unilateral destruction of the labyrinth through intratympanic injection of streptomycin sulfate were only moderately affected by rotation, as indicated by their continued high levels of activity. Rats with intact labyrinths but previous rotation exposure also showed decreased sensitivity to rotation, indicating that ei ther physiological insult or experience (habituation) can produce similar modifications in the response to rotation. Rats were extremely resistant to streptomycin sulfate injected systemi cally; neither morphological damage to the hair cells of the vestibule nor changes in the behovioral response to rotation was found following a total drug dosage of $10,000 \mathrm{mg}$. 
Unclassified

Security Classification

\begin{tabular}{|l}
\hline $14 . \quad$ KEY wORDS \\
\hline \\
Spontaneous Activity \\
Behavioral Measurement \\
Rat \\
Rotation Sensitivity \\
Vestibular Stimulation \\
Comparative Psychology \\
Streptomycin Ototoxicity \\
Habituation (Adaptation) \\
Histological Confirmation
\end{tabular}

\section{INSTRUCTIONS}

1. ORIGINATING ACTIVITY: Enter the name and address of the contractor, subcontractor, grantee, Department of $\mathrm{De}$ fense activity or other organization (corporate author) issuing the report.

2a. REPORT SECURTY CLASSIFICATION: Enter the overall security classification of the report. Indicate whether "Restricted Data" is included. Marking is to be in accordance with appropriate security regulations.

2b. GROUP: Automatic downgrading is specified in DoD Directive 5200.10 and Armed Forces Industrial Manual. Enter the group number. Also, when applicable, show that optional markings have been used for Group 3 and Group 4 as authorized.

3. REPORT TITLE: Enter the complete report title in all capital letters. Titles in all cases should be unclassified. If a meaningful title cannot be selected without classification, show title classification in all capitals in parenthesis immediately following the title.

4. DESCRIPTIVE NOTES: If appropriate, enter the type of report, e.g., interim, progress, summary, annual, or final.

Give the inclusive dates when a specific reporting period is covered.

5. AUTHOR(S): Enter the name(s) of author(s) as shown on or in the report. Enter last name, first name, middle initial. If military, show rank and branch of service. The name of the principal author is an ahsolute minimum requirement.

6. REPORT DATE: Enter the date of the report as day, month, year; or month, year. If more than one date appears on the report, use date of publication.

7a. TOTAL NUMBER OF PAGES: The total page coun should follow normal pagination procedures, i.e., enter the number of pages containing information.

7b. NUMBER OF REFERENCES: Enter the total number of references cited in the report.

8a. CONTRACT OR GRANT NUMBER: If appropriate, enter the applicable number of the contract or grant under which the report was written

8b, \&c, \& 8d. PROJECT NUMBER: Enter the appropriate military department identification, such as project number. subproject number, system numbers, task number, etc.

9a. ORIGINATOR'S REPORT NUMBER(S): Enter the official report number by which the document will be ident ified and controlled by the originating activity. This number must be unique to this report.

9b. OTHER REPORT NUMBER(S): If the report has been assigned any other report numbers (either by the originator or by the sponsor), al so enter this number(s).

10. AVAILABILITY/LIMITATION NOTICES: Enter any limitations on further dissemination of the report, other than those imposed by security classification, using standard statements such as:

(1) "Qualified requesters may obtain copies of this report from DDC."

(2) "Foreign announcement and dissemination of this report by DDC is not authorized."

(3) "U. S. Government agencies may obtain copies of this report directly from DDC. Other qual ified DDC users shall request through

(4) “U. S. military agencies may obtain copies of this report directly from DDC Other qualified users shall request through

(5) "All distribution of this report is controlled Qualified DDC users shall request through .$"$

If the report has been furnished to the Office of Technical Services, Department of Commerce, for sale to the public, indicate this fact and enter the price, if known.

11. SUPPLEMENTARY NOTES: Use for additional explanatory notes.

12. SPONSORING MILITARY ACTIVITY: Enter the name of the departmental project office or laboratory sponsoring (pay ing $(o t)$ the research and development. Include address.

13. ABSTRACT: Enter an abstract giving brief and factual summary of the document indicative of the report, even though it may also appear elsewhere in the body of the technical report. If additional space is required, a continuation sheet shal be attached.

It is highly desirable that the abstract of classified reports be unclassified. Each paragraph of the abstract shall end with an indication of the military security classification of the information in the paragraph, represented as $(T S),(S),(C)$, or (U)

There is no limitation on the length of the abstract. However, the suggested length is from 150 to 225 words.

14. KEY WORDS: Key words are technically meaningful terms or short phrases that characterize a report and may be used as index entries for cataloging the report. Key words must be selected so that no security classification is required. Identifiers, such as equipment model designation, trade name, military project code name, geographic location, may be used as key words but will be followed by an indication of technical context. The assignment of links, roles, and weights is optional. 